\title{
Integrating Sustainability into Business Practices: Learning from Brazilian Firms
}

\author{
Maira Petrini * \\ E-mail address: maira.petrini@fgv.br \\ Fundação Getúlio V argas - EAESP/FGV \\ São Paulo, SP, B razil.

\section{M arlei Pozzebon} \\ E-mail address: marlei.pozzebon@ hec.ca \\ HEC M ontréal \\ M ontreal, Quebec, Canada.
}

\begin{abstract}
This paper proposes a conceptual model to facilitate incorporation of sustainability into business practices, learning from the context of companies operating in Latin A merica - more specifically, in B razil - that excel in terms of sustainability initiatives. Five large companies recognized as leaders in sustainability practices were studied using the grounded theory method. The main result of our study is the identification of a number of influential factors, interconnected according to three broad categories - corporate view, organizational structure and organizational mechanisms - allowing a better understanding of the integration of sustainability into business practices.
\end{abstract}

Key words: sustainability; corporate social responsibility; business practices; grounded theory; Brazilian business context.

Copyright (c) 2010 Brazilian A dministration Review. All rights reserved, including rights for translation. Parts of this work may be quoted without prior knowledge on the condition that the source is identified.

\footnotetext{
* Corresponding author: M aira Petrini

EA ESP/FGV , Rua I tapeva, 474, 9ำ andar, B ela V ista, São Paulo, SP, 01332-000, B razil.
} 


\section{INTRODUCTION}

The concepts of sustainability and corporate social responsibility [CSR] have been among the most important themes to emerge at the global level in the last decade. Sustainability and CSR are seen as comparable concepts in this paper, since both take into consideration environmental, social and economic dimensions and both refer to a long-term perspective based on meeting the needs of the present with responsibility and without compromising the ability of future generations to meet their needs. In light of this, managers have to take into consideration not only increased sales and profits and/or decreased costs, but also the sustainable development of the business itself and the surrounding context. A growing number of companies worldwide have engaged in serious efforts to integrate sustainability into their business practices (J ones, 2003). However, most firms have kept the question of sustainability separate from considerations of business strategy and performance evaluation, areas that are often dominated by purely economic performance indicators (Clarkson, 1995), and more research is needed to promote theoretical and practical advances in that management field.

Although corporate efforts to integrate sustainability into their business practices have begun to be reported in a growing number of publications worldwide, most of them have focused on North A merican and European contexts. A logical and salutary vector extends to scrutiny of the experiences of firms located in other regions, particularly A frica and Latin A merica. O ur research aims to propose a model to facilitate the incorporation of sustainability into business practices, learning from the context of companies operating in Latin A merica - more specifically, in B razil - that excel in terms of sustainability initiatives.

\section{DEFINING CSR AND SUSTAINABILITY}

From a historical point of view, the seminal work of Bowen (1953) was one of the starting points for the field known as corporate social responsibility [CSR]. In our study, we define CSR as a comprehensive set of policies, practices and programs that are integrated into business operations, supply chains and decision-making processes throughout a company, aiming to inculcate responsibility for current and past actions as well as future impacts (Business for Social Responsibility $[B S R]$, 2008). Similarly, the long history of issues surrounding sustainable development notwithstanding, the predominant definition of sustainability was that introduced by the Brundtland Commission's 1987 report: meeting the needs of the present without compromising the ability of future generations to meet their own needs. A sustainable enterprise genuinely contributes to sustainability by delivering economic, social and environmental benefits simultaneously, i.e., achieving the triple bottom line (Dyllick \& Hockerts, 2002; Elkington, 1998). Triangulating with the state and civil society, organizations have been developing new strategies, policies and arrangements and redefining their respective roles, action domains and interdependency (M arrewijk, 2003).

Those two terms - sustainability and CSR - have progressively converged and today they encompass similar dimensions and are often applied as synonymous or comparable terms (E merson, 2003; M azon, 2004). First, both concepts involve multiple levels of analysis (individual, group, firm, community, etc.) and multiple stakeholders (employees, shareholders, clients, suppliers, partners, community members, etc.). Secondly, CSR and sustainability deal with issues related to three distinct spheres that sometimes overlap: social, environmental and economic. It is important to note that the economic sphere is not limited to short-term performance indicators such as return on investment [ROI], but also refers to elements that contribute to long-term financial success, such as a firm's reputation and relationships. Consequently, managing sustainability and CSR implies seeking a balance between short- and long-term considerations, and among the interests of a larger group of stakeholders than those addressed by traditional management (R aynard \& Forstarter, 2002). 
CSR and sustainability have come to represent an important dimension of corporate strategy, with an increasing number of firms trying to determine, monitor and improve the social and environmental impacts of their operations. Despite such an explosion of interest, effective incorporation of sustainability into business practices and management faces serious obstacles, raising the need for more research.

\section{INTEGRATING SUSTAINABILITY INTO BUSINESS PRACTICES}

Organizations are increasingly inclined to integrate society's expectations into their business strategies, not only to respond to rising pressure from consumers, employees and other stakeholders but also to explore opportunities for creating competitive advantage (Bielak, Bonini, \& Oppenheim, 2007; B onini, M endonça, \& Oppenheim, 2006). To this end, management researchers are seeking to identify a set of factors with the potential for facilitating effective integration of sustainability into organizational practices.

Leadership has been recognized as an important factor, promoting the commitment of organizations as a whole (United States Environmental Protection A gency [USEPA], 2001), driving cultural values towards such commitment rather than a form of control (Higgins, 1995). Likewise, Marrewijk (2004) describes a set of ideal types of organizations, and for each type elaborates a system of values and related institutional structures, such as governance and the role of leadership. Fineman (1996) discusses the role of leadership in the process of change, pointing out that green practices take place when managers cultivate employee commitment to belonging to a socially responsible organization. In short, leadership appears to play an important role in the corporate adoption of sustainability practices.

Other factors recognized as promoters of sustainability initiatives are institutional mechanisms such as communication and training. Stone (2006) points out that, in order to achieve a high degree of organizational commitment and to remove obstacles to changes of attitude and involvement, welldefined training and communication plans are key factors in promoting a clear understanding of the role and importance of sustainable practices for organizational strategy and goals.

In a different approach, Tregidga and Milne (2006) analyze corporate reports with a view to understanding the emergence and development of the discourse of sustainability. They discuss the role of communication and reporting mechanisms in building and legitimizing corporate sustainability initiatives and helping to reduce the sense that sustainability and businesses are incompatible. From this standpoint, corporate reports may be seen as a tool for promoting adequate education and information, as pointed out by Stone (2006).

Bansal (2003) proposes that organizational commitment to sustainability is facilitated when top management buy the concept, but also when lower organizational levels engage in sustainability, i.e., when there is congruence between employees' concerns and organizational values. A gents of change can be internal, like those noted so far, or external, such as investors, suppliers, regulatory agencies, and even customers. Henriques and Sadorsky (1999) associate management's perception of stakeholders' pressures with more proactive undertakings towards environmental commitment. Broadening this study, Sharma and Henriques (2005) propose a typology linking different types of stakeholder influence strategies with various sustainability practices adopted by organizations. They not only confirm that stakeholders do have an influence on sustainability practices, but also point to different pressures exerted by stakeholders that affect such practices. Table 1 provides a summary of the influential factors involved in integrating sustainability into business practices identified in the literature review. 
Table 1

Influential Factors I dentified in the Literature R eview

\begin{tabular}{ll}
\hline Summary of influential factors & Sources \\
\hline Leadership & USEPA 2001; Higgins 1995; M arrewijk (2004); Fineman (1996) \\
Governance & M arrewijk (2004) \\
Communication and training & Stone (2006) \\
Reporting & Tregidga and Milne (2006); Stone (2006) \\
Top and lower level commitment & Bansal (2003) \\
Stakeholder pressure & Henriques and Sadorsky (1999); Sharma and Henriques (2005) \\
\hline
\end{tabular}

Our literature review suggests that although researchers are attempting to identify and understand factors that might influence the integration of sustainability by today's firms (Table 1), very few studies, if any, have proposed a more integrated view of these factors. The recent article by B asu and Palazzo (2008) is one of the rare few that go further in this direction, considering internal and external influences, proposing a group of cognitive, linguistic and conative dimensions in order to identify an organization's intrinsic orientation toward the adoption of CSR (Table 2).

Table 2

Basu and Palazzo's (2008) Dimensions for the Adoption of C SR

\begin{tabular}{ll}
\hline Dimension & Examples of influential factors \\
\hline Cognitive & Organizational identity, orientation, legitimacy, values \\
Linguistic & Organizational communication, reporting, justifications \\
Conative & Organizational coherence, commitment \\
\hline
\end{tabular}

Note. Sources: based on B asu and Palazzo's (2008).

The cognitive dimension has to do with aspects involving corporate identity, orientation and legitimacy, organizational beliefs and values regarding the adoption of sustainability (Henriques \& Sadorsky, 1999; Higgins, 1995; USEPA, 2001). The linguistic dimension involves organizational modes of justification and is directly related to considerations of transparency and communication (M arrewijk, 2004; Stone, 2006; Tregidga and M ilne 2006). The conative dimension concerns the way organizations tend to behave, involving coherence among (and by means of) practices and strategic policies and degrees of commitment (Bansal, 2003; Fineman, 1996; M arrewijk, 2004; Sharma and Henriques, 2005).

While the three dimensions of Basu and Palazzo (2008) encompass a collection of factors that have garnered support in previous research, we still identify a gap when it comes to understanding better exactly how these factors interact as an influence on the incorporation of sustainability into business practices. Furthermore, the bulk of research into sustainability focuses on developed countries. Our research has, therefore, two aims: firstly, to make conceptual advances in the area of the integration of sustainability into firms' business practices through a model that identifies and interconnects influential factors; secondly, to promote a better understanding of how successful companies operating in a Latin A merican context - more specifically, in B razil - have been in promoting such integration. We believe that from observed similarities, and even more from differences, between conceptual models produced by the so-called developed and developing worlds, we can build theoretical framew orks from which both worlds can learn. 


\section{ReSEARCH METHOD}

We adopted a grounded theory approach, whose main characteristics are as follows (Glaser \& Strauss, 1967): (1) the main thrust of the method is to construct a theory, not merely to codify and analyze data; (2) as a general rule, the researcher must not define a conceptual framework before beginning research (so as to allow concepts to emerge without predefined frames); and (3) analysis and conceptualization are realized through the process of collecting data, which are constantly compared with emerging categories, thereby enriching them, establishing relationships among them or originating a new one.

Grounded theory is, above all, a form of qualitative research that seeks to generate new theories by using basic elements: concepts, categories and properties. The emphasis in grounded theory is on learning, starting from data (interactive and inductive) rather than a previously existing theory (deductive). Furthermore, the greatest difference between grounded theory and other qualitative research methods is its specific focus on development of a theory by means of continuous interdependence between collecting and analyzing data. Grounded theory provides a methodological structure sometimes absent in other qualitative approaches without sacrificing flexibility or rigor (Calloway \& K napp, 2005; Strauss \& Corbin, 1997).

Table 3

\section{G rounded Theory in 9 Steps}

\begin{tabular}{|c|c|c|}
\hline Phase & & M ain activities \\
\hline \multicolumn{3}{|c|}{ Research Design Phase } \\
\hline Step 1 & Review of technical literature & Defining the research question \\
\hline Step 2 & Selecting cases & Theoretical (not random) sampling \\
\hline Step 3 & $\begin{array}{l}\text { Develop rigorous data collection } \\
\text { protocol }\end{array}$ & $\begin{array}{l}\text { Defining themes that delineate the boundaries of the } \\
\text { research question and building an initial guide for } \\
\text { interviews. }\end{array}$ \\
\hline Step 4 & Entering the field & $\begin{array}{l}\text { Overlapping data collection and analysis } \\
\text { Using flexible and opportunistic data collection methods }\end{array}$ \\
\hline \multicolumn{3}{|c|}{ Data Collection Phase } \\
\hline Step 5 & Data ordering & Displaying events chronologically \\
\hline \multicolumn{3}{|c|}{ Data Analysis P hase } \\
\hline Step 6 & A nalyzing data & Using coding and memo \\
\hline Step 7 & Theoretical sampling & $\begin{array}{l}\text { Looking for theoretical replication across } \\
\text { Returning to step } 4 \text { (until theoretical saturation) }\end{array}$ \\
\hline Step 8 & Reaching closure & L ooking for theoretical saturation when possible \\
\hline \multicolumn{3}{|c|}{ Literature Comparison Phase } \\
\hline Step 9 & $\begin{array}{l}\text { Compare emergent theory with } \\
\text { extant literature }\end{array}$ & $\begin{array}{l}\text { M aking comparisons with conflicting frameworks } \\
\text { M aking comparisons with similar frameworks }\end{array}$ \\
\hline
\end{tabular}

Note. Sources: adapted from Pandit (1996).

In this study, there was one particular reason for the choice of grounded theory: its emphasis on learning that emerges from data and does not start from an existing theoretical point of view. Table 3 presents a summary of the grounded theory steps that guided this research. The literature review was 
considered a means of refining the research question as well as providing data to be integrated in the final stage of the constant comparison technique of analysis, described later in this paper (step1).

\section{SELECTION OF CASES}

The field work was carried out in the state of São Paulo in southwestern Brazil, which features effervescent business movement towards sustainability. Grounded theory points out the importance of theoretical rather than random sample selection (step 2). With this goal in mind, we established the three following criteria for selecting outstanding Brazilian firms in terms of their corporate sustainability agenda (of which the selected companies should meet at least two): (1) the company should be an advocate of or signatory to at least one of the various principles, norms, certifications or reports related to sustainability (GRI, ISO14001, SA 8000, etc.); (2) the company should be indexed by the Dow Jones Sustainability Index and/or the Bovespa Sustainable Business Index (a Brazilian index); (3) the company should have received awards or public recognition for actions related to sustainability.

Based on these criteria, five large companies recognized as Brazilian leaders in sustainability practices were selected, denominated as FIN 1, FIN2, FIN 3, IND1 and COS1. T wo of them (FIN 1 and IND1) met two of the above criteria, and the others (FIN2, FIN3, and COS1) met all three of the designated criteria. FIN1, FIN2 and FIN3 are banks, IND1 and COS1 are manufacturers of plastic pipes and cosmetics, respectively (a detailed description of the companies may be obtained upon request).

\section{DATA COLLECTION}

In all the cases, data were collected from semi-structured interviews and documentation (such as yearly financial reports, social balances and website content). A research protocol was drawn up to guide the entire data-gathering process (step 3). The interviews were conducted and recorded by the first author. The only exception involved company IND1, where the interviews were performed by another researcher of our research team, and the transcriptions were integrated into the analysis process.

According to grounded theory, data should be collected and analyzed simultaneously. Thus the interviews began with broader questions and evolved towards more specific ones, as theory (a conceptual model) began to emerge from data. The initial stages consisted primarily of defining themes, which were further elaborated as the study evolved. A consequence of overlapping data collection and analysis was the more purposive selection of respondents. From the emergence of initial concepts tentatively articulated vis-à-vis each other (embryo of a conceptual model), the identified categories were further elaborated, leading to new interviews (step 4). In sum, we conducted 16 interviews in the first round of interviewing, and 5 in the second round, totaling 21 interviews (Table 4). 
Table 4

\section{Summary of Data Collection through Interviews}

\begin{tabular}{|c|c|c|c|c|c|}
\hline \multirow[t]{2}{*}{ Firm } & \multirow[t]{2}{*}{ Total } & \multicolumn{2}{|l|}{ First round } & \multicolumn{2}{|l|}{ Second round } \\
\hline & & Function of respondents & $\begin{array}{l}\text { Duration } \\
* *\end{array}$ & Function of respondents & $\begin{array}{l}\text { Duration } \\
* *\end{array}$ \\
\hline FIN1 & $\begin{array}{l}4 \text { respondents } \\
5 \text { interviews }\end{array}$ & $\begin{array}{l}\text { (a) business manager } 1^{*} \\
\text { (b) executive planning manager } 1 \\
\text { (c) senior planning analyst }\end{array}$ & $11 / 2$ hours & $\begin{array}{l}\text { (a) business manager } 1^{*} \\
\text { (b) business manager } 5\end{array}$ & 1 hour \\
\hline \multirow[t]{2}{*}{ Firm } & Total & First round & & Second round & \\
\hline & & F unction of respondents & $\begin{array}{l}\text { Duration } \\
* *\end{array}$ & Function of respondents & $\begin{array}{l}\text { Duration } \\
* *\end{array}$ \\
\hline FIN2 & $\begin{array}{l}4 \text { respondents } \\
5 \text { interviews }\end{array}$ & $\begin{array}{l}\text { (a) sustainability senior analyst* } \\
\text { (b) sustainability executive } \\
\text { manager } \\
\text { (c) business manager } 2 \\
\text { (d) business manager } 3\end{array}$ & 2 hours & $\begin{array}{l}\text { (a) sustainability senior } \\
\text { analyst } *\end{array}$ & $1 \frac{1}{2}$ hours \\
\hline FIN3 & $\begin{array}{l}3 \text { respondents } \\
3 \text { interviews }\end{array}$ & $\begin{array}{l}\text { (a) sustainability coordinator } 1 \\
\text { (b) business manager } 4 \\
\text { (c) support area manager }\end{array}$ & $11 / 2$ hours & - & - \\
\hline $\cos 1$ & $\begin{array}{l}3 \text { respondents } \\
3 \text { interviews }\end{array}$ & (a) sustainability coordinator 2 & $4 \frac{1}{2}$ hours & $\begin{array}{l}\text { (a) executive planning } \\
\text { manager } 2 \\
\text { (b) systems analyst } 3\end{array}$ & $1 \frac{1}{2}$ hours \\
\hline IND1 & $\begin{array}{l}5 \text { respondents } \\
5 \text { interviews }\end{array}$ & $\begin{array}{l}\text { (a) quality control and } \\
\text { environment director } \\
\text { (b) social communication director } \\
\text { (c) IT manager } \\
\text { (d) systems analyst } 1 \\
\text { (e) systems analyst } 2\end{array}$ & 2 hours & - & - \\
\hline
\end{tabular}

Note. * Two interviews with the same respondent; ** A verage duration of each interview

All the interviews were conducted between $M$ arch and September 2006. The interviewees - business managers, sustainability coordinators, senior planning analysts and IT managers - were selected based on their in-depth knowledge of the firm's sustainability processes and practices and the unique perspective they could provide.

\section{DATA ANALYSIS}

Based on the interviews and on the documental research, a detailed and chronological description of each company was prepared (step 5). From this point on, different grounded theory techniques were used (steps 6 and 7). The data were read and categorized in concepts intrinsically suggested by the data as such; concepts emerging from the analysis were grouped into themes; and, finally, the themes gave rise to categories, and subcategories generated properties (open coding). The establishment of relationships among categories and properties is called axial coding, and this process was performed for each of the investigated cases.

After all the cases were analyzed, the data were then reexamined and recoded using the identified preliminary scheme of categories and properties and following the constant comparison method. When 
data were reexamined, new concepts were able to emerge - new because they did not fit into the extant scheme of categories and properties, generating questions and insights regarding the model requiring further investigation. These questions and insights led to new interviews - to clarify understanding and foster development of categories, properties and their relations - and to a return to the data-gathering phase. The interaction between data and concepts reached a conclusion when re-analyses no longer led to the emergence of new categories or subcategories or to questions regarding those extant, reaching what is termed theoretical saturation (step 8).

Finally, we juxtaposed the model that emerged from the analysis phase with the existing referential framew orks and models found in the literature, which helped to corroborate or refine some categories and properties of the emergent model (step 9).

\section{Results: A New MOdel for InTEgrating Sustainability into Business Practices}

The model presented in Figure 1 represents the main outcome of this research. Grounding from systematic execution of the 9 steps of the adapted grounded approach, this model is original, growing out of the Brazilian context, and facilitates integration of sustainability and social responsibility into business practices. The model identifies a group of institutional factors that serve as drivers or facilitators of such integration. The model consists of three broad categories: corporate view, organizational structure and organizational mechanisms. Within each category we identified subcategories or properties between which relationships were established.

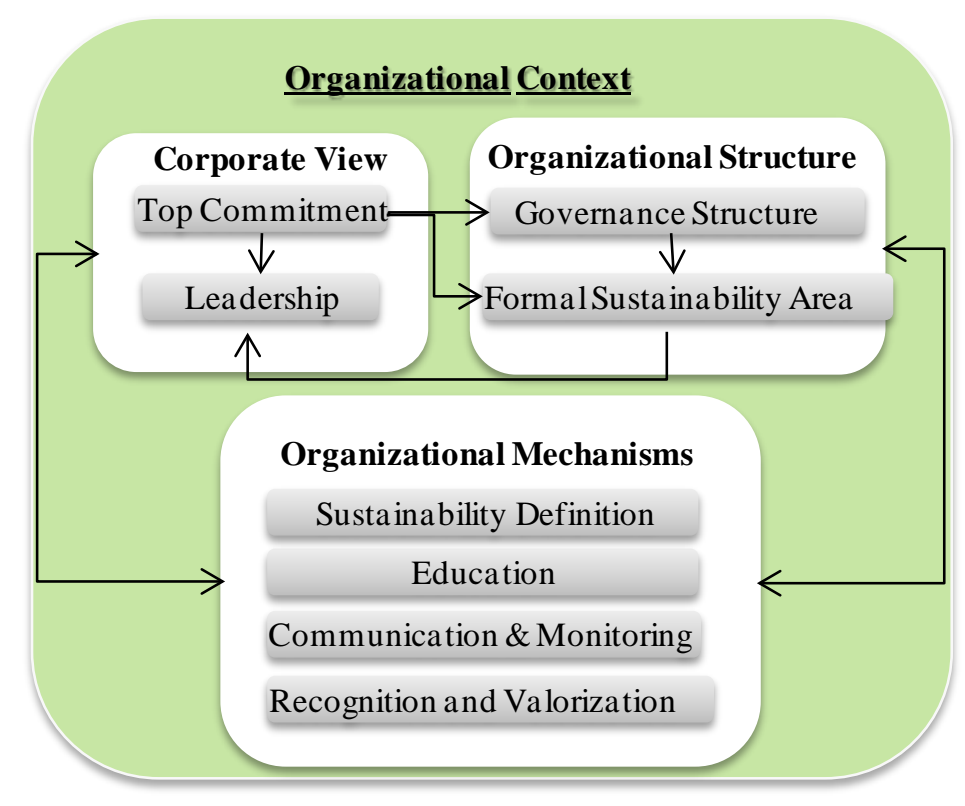

Figure 1. Conceptual M odel for the Integration of Sustainability into Business Practices.

Top management commitment towards sustainability is seen as the starting point for integrating sustainability into business practices. This high-level commitment enables changes in the organizational structure that put the sustainability outlook into action by means of new or adapted governance structures, such as committees and commissions dealing with sustainability issues, and by formally inserting into the organizational chart an area or department whose purpose is to make sustainability practices a reality in the firm's daily practices. Top-level commitment acts as a promoter of the sustainability vision, making possible the emergence of sustainability leadership at different organizational levels. Leadership, in turn, is reinforced by formalization of the sustainability area within the organizational structure. 
Finally, corporate view and organizational structure allow implementation of a set of organizational mechanisms that will legitimize and consolidate the integration of sustainability by: providing a clear definition of sustainability's role within the firm; implementing an educational program to promote sustainability internally and externally; implementing clear mechanisms for communication and monitoring; implementing a system of recognition and valorization of sustainable practices and initiatives.

\section{CORPORATE VIEW}

Corporate view has two important sub-categories or properties: senior management commitment and leadership. Clearly, top-level commitment appears the major driver for integrating sustainability into business practices, promoting a clear vision and enabling other stakeholders to commit. In our five cases, involving firms in a mature phase of integrating sustainability, it was clear that integration was instantiated through a top-down process.

The commitment of senior executives is the starting point for legitimatization of a corporate vision of sustainability. Such a commitment often rests on the belief that business growth requires a context that offers quality of life to employees and citizens at large and preserves the environment and natural resources. The private sector, therefore, would play a fundamental role in reconciling financial performance with social and environmental responsibility. In all studies, in organizations showing higher levels of maturity with regard to adoption of sustainability, the importance of top management commitment was clearly evident. In one of the companies studied (FIN2), a comment by one respondent illustrates and reinforces this assertion:

"This business of sustainability exists only because it came from the top" (FIN2).

The commitment of senior management was the starting point for the sustainability ideal to take root, and it rested on the belief that it is possible to reconcile financial results with social and environmental responsibility. However, as the model indicates, the top-down process seems to be a necessary but not a sufficient condition, since other mechanisms or properties emerged as significant. Upper-level commitment creates conditions for the emergence of leadership at different organizational levels, thereby helping to generate the necessary conditions for sustainability practices that truly permeate employees' everyday practices.

"Social and environmental issues are the responsibility of everyone, starting with the president, then the board of directors, and successively to lower levels" (IND1).

It is also important to note that, even given heavy top-level commitment to creating conditions for leadership to emerge, there are always individual differences in the way that people appropriate these values, as illustrated by the comment of a respondent explaining why there are sustainability practices at differing levels of maturity:

"within some business areas, there are people who are really convinced when it comes to the sustainability issue. Then they bring it into the day-to-day operation vigorously" (FIN 3).

This empirical indication that there are numerous CSR practices varying in maturity within the same organization reinforces our findings, i.e., that in addition to top-level commitment and leadership in sustainability, organizations need to put in place a formal structure facilitating sustainability practice. This organizational structure, which is explained below, aims to minimize possible discrepancies that might result from lack of coordination and align executive level commitment and organizational practices. 


\section{ORGANIZATIONAL STRUCTURE}

Although corporate view is the driver for the adoption of sustainability, our model recognizes the fundamental importance of adapting the organizational structure. We distinguish two distinct properties or factors: (3) governance structure and (4) the creation of a formal sustainability area or department. The firm's governance structure should be adapted to incorporate governance tools for managing sustainable initiatives: directive councils, committees and commissions overseeing discussion and decision-making on sustainability issues (e.g., analyzing projects for reducing the use of water as a resource material for a product; deciding to replace non-organic products with biodegradable ones; establishing socio-environmental criteria concerning the firm's relationship with suppliers).

In addition to adjustments in the governance structure, the model suggests the importance of creating a sustainability area or department and its formalized inclusion in the board of directors.

One of the organizations studied (FIN3) clearly illustrates that the mere existence of a governance structure oriented to promoting discussion of CSR issues does not, in itself, guarantee the genuine incorporation of sustainability into business. Despite the existence of a committee responsible for policies, CSR guidelines and a commission for implementing those policies, sustainability actions may still remain detached from overall company strategy. One explanation for this may be the fact that for the chairman of the committee responsible for CSR policies and CSR guidelines, sustainability is just one of numerous issues to be dealt with. In other words, despite its importance, sustainability is not the primary function.

The formalization in the organizational chart of an area or department focused on sustainability and therefore the existence on the board of a sustainability director - has been clearly shown as an effective means of officially and formally integrating CSR into business strategy.

"W e have an executive [of sustainability] that reports directly to the President of FIN2. As a top executive, he manages actions plans, strategic objectives and his own budget ... he (the executive of sustainability) is not reporting to anyone on the board" (FIN2).

"A management sustainability area was created to meet the growing need to integrate issues of sustainability and to attribute strategic importance to this [sustainability] issue" (COS1).

A $n$ important finding that lends emphasis to the importance of formalizing an area of sustainability as an integral part of the executive board was identified by studying the role of some institutes and foundations. The creation of a separate institute or foundation engaged with social and environmental goals is relatively common in large companies. Our research results suggest that such institutes and foundations develop and implement a series of socio-environmental initiatives, but without their being integrated into the original business, acting alone and showing no connection with strategic objectives of the head office. The projects are primarily philanthropic and, in some cases, represent a strategy for reinforcing a brand or for benefiting from tax breaks. Although this opportunistic presence is common, one of the organizations (FIN2) expressed concern over looking at the actions of their institute with a view to integrating it into their business.

Finally, the corporate view and the organizational structure allow the implementation of a set of Organizational M echanisms that will legitimize and consolidate integration of sustainability by: (a) providing a clear definition of sustainability's role within the firm; (b) implementing an educational program to promote sustainability internally and externally; (c) implementing clear mechanisms for communication and monitoring; (d) implementing a system for recognizing and valuing sustainable practices and initiatives. 


\section{ORgANIZATIONAL MECHANISMS}

This category is characterized by four properties: (1) clear definition of the role of sustainability as part of organizational vision; (2) heavy focus on training and education; (3) constant monitoring and communication of the firm's sustainability initiatives and advances; (4) establishment of a recognition strategy to award employees' performance in terms of sustainability practices.

The first element is related to building a corporate vision of what the organization seeks in terms of sustainability. It is not enough to set strategic goals and then outline action plans and budgets to achieve them. It is necessary to check whether employees do, in fact, understand what the board of directors wants, and also to make it possible for people to communicate and understand the concepts at all organizational levels, thereby enabling them to be translated into everyday actions.

In this view, the sustainability area would function as a kind of consultative agency, providing the business units or departments with knowledge and the best practices for developing sustainable business process and products, and buttressing the organization through the alignment of sustainability plans across the firm. According to our interviewees, in firms with limited maturity in terms of a sustainability agenda, the sustainability area might take on a more directive role by acting as an auditor, monitoring practices and processes, and seeking explanations when goals are not achieved. For instance, the purchasing department could be audited in terms of the goal of selecting and hiring suppliers that do not employ child labor. A s maturity ripens, the sustainability area will be able to play a more consul tative role, since sustainability practices have al ready been integrated into daily routine:

"The question is: can this issue [sustainability] generate business value? Business areas seek to help us in understanding how sustainability can add value to their business" (FIN2).

This more consultative role is consonant with Higgins' (1995) assertion that leadership should represent the firm's values rather than a form of control.

B razilian firms having greater maturity in integration of sustainability into business clearly indicated that education is the vehicle by means of which one disseminates sustainability to all areas.

"We use different tools to ensure the incorporation of sustainability into business and education is one of them ... it [education] is used for people to adopt these values [of sustainability]" (COS1).

"education is the vehicle through which we integrate sustainability more easily to all areas" (FIN2).

The ultimate aim of focusing on education is to create organizational behavior, transform people and internal ize sustainability concepts in the everyday routine of all areas.

In addition to training and education, a communication plan regarding the evolution of firms' sustainable and responsible actions is needed. The organizations we investigated used different mechanisms for communication: creation of a network of employees who act as disseminators of responsible management principles (COS1); reports and social balances that communicate socioenvironmental performance (FIN2, COS1 and IND1); or campaigns to promote socially responsible actions, such as implementation of waste recycling in the company and reduction of the use of paper or disposable materials (FIN2, COS1 and IND1).

Finally, communication is also closely linked to the focus on training and education, since the feedback obtained allows improvement in the implementation of values and processes that align CSR with business strategy.

"For each campaign we make promotional material, messages shock wave in computers, billboards ... $100 \%$ of our employees attend related lectures" (IND1). 
Finally, collective and individual action is reinforced by the presence of mechanisms for appraisal and acknowledgement of responsible action, which also promote the employee's perception that sustainability principles are not merely politically correct discourse. Examples of appraisal and acknowledgement initiatives include: increasing the number of vacation days for employees who take part in voluntary programs (IND1); setting goals for sales of sustainable products, with a special bonus; in other words, granting financial recognition equivalent to that pertaining to non-sustainable products, even when the amount of sustainable products is smaller, since the focus is not on absolute value, but on the percentage of the sustainable product's growth (FIN2).

Our research suggests that in more mature organizations mechanisms for acknowledgement are present at all organizational levels, not only the operational:

"To strengthen the alignment of our executives with the goals of the SBSC, members of the executive committee and the country managers of each country receive a bonus equivalent to 20 or $25 \%$ of their salary for meeting the objectives aligned with the triple bottom-line" (IND1).

In some cases, the mechanisms for acknowledgement are extended to the value chain:

“W e implement an award for rewarding clients' social and environmental projects, aiming to provide future generations with a better place in which to live" (IND1).

\section{DISCUSSION: BACK TO THE LITERATURE}

Although constructed through a purely inductive process, as suggested by grounded theory, in the last phase of constant comparison analysis we compared our model with existing literature and found several points of convergence and support. Table 5 presents the results of comparison of categories and properties that constitute the empirical model and principles and the dimensions identified by B asu and Palazzo (2008) in the literature review.

Table 5

\section{Results of Comparing the Grounded M odel with the L iterature R eview}

\begin{tabular}{|c|c|c|c|}
\hline Categories and properties & Existing & New & $B \& P(2008)$ dimension \\
\hline \multicolumn{4}{|l|}{ Corporate view } \\
\hline Top commitment & $x$ & & $\begin{array}{l}\text { Cognitive } \\
\text { Conative }\end{array}$ \\
\hline Leadership & $\mathbf{x}$ & & Cognitive \\
\hline \multicolumn{4}{|l|}{ Organizational structure } \\
\hline Governance structure & $x$ & & Conative \\
\hline Formal sustainability area & & $\mathbf{X}$ & $\begin{array}{l}\text { Cognitive } \\
\text { Conative }\end{array}$ \\
\hline \multicolumn{4}{|l|}{$\underline{\text { Organizational mechanisms }}$} \\
\hline Formal definition & $x$ & & $\begin{array}{l}\text { Linguistic } \\
\text { Conative }\end{array}$ \\
\hline Education & $\mathbf{x}$ & & Linguistic \\
\hline Communication and monitoring & $x$ & & Linguistic \\
\hline Recognition and valorization & & $\mathbf{x}$ & Conative \\
\hline Interrelations among them & & $\mathbf{x}$ & Conative \\
\hline
\end{tabular}

Note. Sources: based on B asu and Palazzo (2008). 
The first category - corporate view - identifies the importance of top-level commitment and leadership, which is strongly supported by authors such as Higgins (1995), Fineman (1996) and USEPA (2001). In order to translate the top-level sustainability view into daily sustainability practices across all organizational levels, the corporate view should lead to changes in organizational structure. This category is also supported by several authors, such as Marrewijk (2004), who underlines the importance of leadership and appropriate governance mechanisms. The organizational mechanisms category is supported by several authors (Stone, 2006; Tredidga \& M ilne, 2006). Finally, regarding Basu and Palazzo (2008), all the dimensions proposed in their work overlap somewhat with the categories of our conceptual model. For example, our research indicates that when top management changes organizational structure and includes a formal sustainability area in the firm's organizational chart, they are making explicit the important place occupied by sustainability goals. We identify relationships with the cognitive (regarding legitimacy) and the conative dimension (regarding consistency).

A $n$ important contribution of our research is the identification of two influential factors that have not been reported in the reviewed literature - the creation of a formal sustainability area and the design of a recognition and appraisal mechanisms. Although these factors have emerged from the experience of Brazilian firms, we believe that future research would corroborate their significance, not only for the Latin A merican context but for other contexts as well. A second contribution of our model is highlighting the interconnectedness among categories and properties, hel ping to better understand how influential factors facilitate the integration of sustainability in a logical and coherent way.

\section{Sustainability AND ORGANIZATIONAL ChANGE}

The primary aim of this research was to propose a conceptual model for integration of sustainability into business practices by means of identifying factors that promote or facilitate the process of integration. However, the more we analyzed the final conceptual model, the more we found a connection with the area of organizational change - a theme that did not fall within the scope of the research and was not included in the literature review section. Organizational change is a well-known field of research that has generated an enormous amount of literature and a wide range of theoretical references and frameworks. We believe that future research might strengthen the relation between our conceptual model and organizational change theories to develop a theory of organizational change contextually addressed to the integration of sustainability. On the one hand, authors such as Dunphy, Griffiths and Benn (2003) discuss important changes for reaching sustainability, but the theme is treated in a general manner without providing an integrated model for organizational change and sustainability. On the other hand, Burke and Litwin (2002) propose an integrated model of causal relations among factors that lead organizations to embark on a process of change, but it is a generic model, one not adapted to the context of sustainability.

In order to develop a specific model for organizational change toward sustainability, a combination of several models could be valuable. For instance, taking the framework proposed by Burke and Litwin (2002) as a starting point, Figure 2 shows that they make a distinction between transformational and transactional changes. 


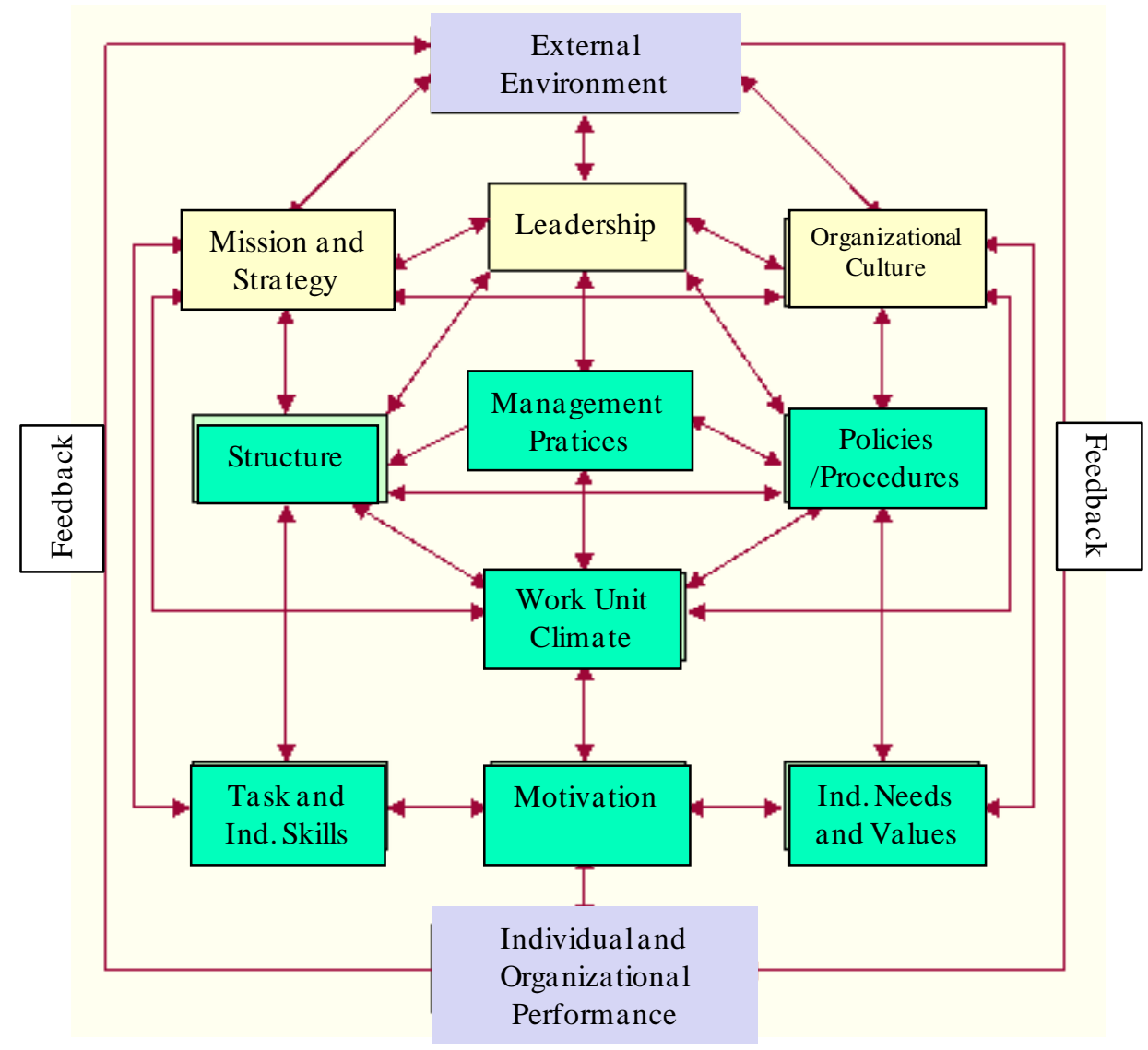

Figure 2. M odel of Organizational Performance and Change Sources: B urke and Litwin (2002, p. 119).

Transformational changes occur in response to the external environment, which directly affects the mission, strategy, leadership and culture of an organization. Transactional changes, on the other hand, are related to structure, systems, management practices and organizational environment. These two types of change - transformational and transactional - jointly affect motivation which, in turn, affects performance. Closing the cycle, organizational performance may affect the external environment.

$M$ any of the factors presented by Burke and Litwin (2002) are found in the categories and properties identified in our conceptual model, e.g., leadership and organizational structure. Other factors are comparable, e.g., management mechanisms. Other factors were not present in our model, e.g., external environment, which, for Burke and Litwin (2002), is the main driver for change. Overall, it seems to us that a strong relation exists between organizational change and integration of sustainability into the company's business practices. Our research confirmed, in various aspects, the fact that, ultimately, incorporation of sustainability into business practice is possible only when decisions are based on respect for the rights, values and interests of all those who, directly or indirectly, are affected by the company's operation - and this will, invariably, involve organizational changes. A dditional research is needed to better explore this relation and evaluate whether or not various organizational change factors adhere to the incorporation of sustainability until more influenced and influencing variables of the workplace climate (transactional aspects) are differentiated from those influenced by the organizational culture (transformational aspects). 


\section{CONCLUSION}

Our study makes a number of contributions to theory and practice in the area of sustainability management. Grounding from systematic analysis of empirical data gathered from Brazilian enterprises that excel in terms of sustainable practices, and using an adapted grounded approach, the conceptual model proposed is original and seeks to provide a comprehensive way to integrate sustainability and social responsibility into business practices from a Latin American perspective. Here we outline two main theoretical contributions.

First, regarding literature on sustainability models, the proposed framework compiles, supports and integrates existing elements of literature in a consistent and innovative way. Of the eight properties identified in the model, six had al ready been identified by previous studies and two are new. They are now articulated within three sound categories: corporate view, organizational structure and organizational mechanisms. Overall, the proposed model allows better understanding of the relationships among properties and categories, which seems essential to integrating sustainability into business practices.

The second contribution regards our focus on the Latin A merican context. Taking into account the paucity of studies reporting the state of sustainability and CSR in regions other than North A merica and Europe, this paper provides a rich illustration of sustainability practices identified in Brazilian firms. Our results indicate that, despite the perception that governments in Latin A merica are less involved than governments in other parts of the world in sustainability-oriented ethical obligations for firms, we might find a considerable degree of involvement among Latin A merican firms in specific regions where sustainability emerges as a strong movement with a particular local flavor. Our research increases developed countries' knowledge of models practiced in different contexts, namely, the socalled emergent countries with a huge potential for economic growth in the coming decades.

In terms of practical contributions, we outline actionable characteristics of the conceptual model proposed, which is a corollary of the methodological approach chosen. Since we have adopted a grounded approach, in which the conceptual model emerges from empirical data, we have built a model growing out of the context of B razilian firms strongly committed to sustainability, producing an outcome which reflects the daily practices of outstanding firms that, regardless of the region in which they are located, can provide practical lessons for firms elsewhere. The plausibility of the proposed model is one of the strongest points of the present research.

\section{REFERENCES}

Bansal, P. (2003). From issues to actions: the importance of individual concerns and organizational values in responding to natural environmental issues. Organization Science, 14(5), 510-527.

Basu, K., \& Palazzo, G. (2008). Corporate social responsibility: a process model of sensemaking'. The Academy of M anagement Review, 33(1), 122-136.

Bielak, D., Bonini, S. M. J., \& Oppenheim, J. M. (2007). CEOs on strategy and social issues. The M ckinsey Quarterly, 4, 1-8.

Bonini, S. M . J, M endonça, L. T., \& Oppenheim, J. M . (2006). When Social Issues Become Strategy. The M ckinsey Q uarterly, 2, 20-32.

Bowen, H. R. (1953). The social responsibilities of the businessman. N ew Y ork: Harper and Row. 
Burke, W., \& Litwin, G. H. (2002). BurkeLitwin casual model of organizational change. In W.W. Burke (Org.), Organization change: theory and practice (pp. 195-216). London: Sage Publications.

Business for Social Responsibility. (2008). Business for social responsibility. Retrieved M ay 30, 2007, from http://www.bsr.org/about/bsr-report.cfm

Calloway, L., \& K naap, C. (2005). U sing grounded theory to interpret interviews. Retrieved M ay 28, 2007, from http://csis.pace.edu/ knapp/A IS95.htm

Clarkson, M. B. E. (1995). A stakeholder framework for analyzing and evaluating corporate social performance. The Academy of M anagement Review, 20(1), 92-117.

Dunphy, D., Griffiths, A., \& Benn, S. (2003). Organizational change for corporate sustainability - a guide for leaders and change agents of the future. N ew Y ork: R outledge Publishers.

Dyllick, T., \& Hockerts, K. (2002). Beyond the business case for corporate sustainability. Business Strategy and the Environment, 11(2), 130-141.

Elkington, J. (1998). Cannibals with forks: the triple bottom line of 21st century business. Gabriola Island: New Society Publishers.

Emerson, J. (2003). The blended value proposition: integrating social and financial returns. California M anagement Review, 45(4), 35-51.

Fineman, S. (1996). Emotional subtexts in corporate greening. O rganization Studies, 17(3), 479-500.

Glaser, B., \& Strauss, A . (1967). The discovery of grounded theory. Chicago: A Idine.

Henriques, I., \& Sadorsky, P. (1999). The relationship between environmental commitment and managerial perceptions of stakeholder importance. Academy of M anagement J ournal, 42(1), 8799.

Higgins, T. E. (1995). Pollution prevention handbook. B oca Raton: Lewis Publishers.

Jones, T. M. (2003). A n integrating framework for research in business and society. Academy of M anagement Review, 8(4), 55-64.

Marrewijk, M. van (2003). Concepts and definitions of CSR and corporate sustainability: between agency and communion. J ournal of Business Ethics, 44(2-3), 95-105.

Marrewijk, M. van (2004). A value based approach to organization types: towards a coherent set of stakeholder-oriented management tools. J ournal of Business E thics, 55(2), 147-158.

Mazon, R. (2004). U ma abordagem conceitual aos negócios sustentáveis: manual de negócios sustentáveis. São Paulo: FGV -EAESP.

Pandit, N. R. (1996). The creation of theory: a recent application of the grounded theory method. The Qualitative Report, 2(4), 1-14. Retrieved May 5, 2007, from http://www.nova.edu/ssss/QR/QR2-4/pandit.html

Raynard, P., \& Forstarter, M. (2002). Corporate social responsibility: implications for small and medium enterprises in developing countries. Retrieved June 10, 2007, from http://www.unido.org/doc/5162

Sharma, S., \& Henriques, I. (2005). Stakeholder influences on sustainability practices in the Canadian forest products industry. Strategic M anagement J ournal, 26(2), 159-180. 
Stone, L. (2006). Limitations of cleaner production programmes as organisational change agents. II. L eadership, support, communication, involvement and programme design. J ournal of Cleaner Production, 14(1), 15-30.

Strauss, A., \& Corbin, J. (1997). Grounded theory in practice. L ondon: Sage Publications.

Tregidga, H., \& Milne, M. (2006). From sustainable management to sustainable development: a longitudinal analysis of a leading New Zealand environmental reporter. Business Strategy and the Environment, 15(4), 219-241.

United States Environmental Protection Agency. (2001). An organizational guide to pollution prevention.

Retrieved

July

18 ,

2007,

from

http://www.ecy.wa.gov/programs/hwtr/P2/printguid.pdf 